\title{
A LAND-USE SIMULATION MODEL BASED ON THE BIDDING COMPETITION AMONG ACTIVITIES
}

\author{
By Kozo AMANO*, Tsunekazu TODA** and Hirofumi ABE***
}

\begin{abstract}
In this paper, a land-use simulation model based on the concept of bid price is proposed. This model has been developed with the aim of applying it to an area where land use is complex and land prices play an important role in the formation of land use, as happens in urban areas in Japan. The future land-use pattern is estimated by simulating a bidding competition among land-use activities in each hypothetical lot. The model is applied to the Osaka Prefectural Area and its validity is examined.

Keywords : land-use simulation model, land market, bidding competition, land price estimation, impact analysis
\end{abstract}

\section{INTRODUCTION}

The creation of a sound urban environment must be based on rational and systematic planning. However, it has become difficult to implement effective urban and regional planning in Japan. This is partly due to rising land prices and complex land-use patterns in urban areas.

Various trials in the analysis and the modelling of land markets in an urban area have been performed since the mid-1960 s. Alonso (1964) proposed a famous bid-rent theory to explain the formation of urban land use. His theory was expanded by many researchers (Mills 1967, Muth 1969, Beckmann 1969) and has led to the establishment of the New Urban Economics. Empirical studies on bid rent and bid price have also been carried out (see Anas 1982), and there have been several trials to introduce the concept of bid price to operational land-use models (Herbert and Stevens 1960, Ingram, Kain and Ginn 1972). However, most of the models have not been very successful because of the difficulty to simulate land-use changes correctly, large data requirements and computational problems. Moreover, these models were developed to apply to housing markets in an urban area, and not to a general land market.

In Japan, several land-use models focussing on the relationship between land use and land price have been proposed. Aoyama and Morisugi (1970) estimated the locational quality of land by applying the Hayashi's qualitative discriminant analysis. They discussed the relationship among the estimated locational quality, the land price and the land-use pattern in each one kilometer square grid. Nakamura,

* Member of JSCE, Dr. Eng., Professor, Department of Transportation Engineering, Kyoto University (Yoshida-Honmachi, Sakyo-ku, Kyoto)

** Member of JSCE, Dr. Eng., Associate Professor, Department of Transportation Engineering, Kyoto University (YoshidaHonmachi, Sakyo-ku, Kyoto)

*** Member of JSCE, Dr. Eng., Associate Professor, Department of Civil Engineering, Okayama University (3-1-1 Tsushima-Naka, Okayama) 
Hayashi and Miyamoto (1981) developed a land-use model using the idea of locational surplus, which was defined as a difference between the average expected utility and the average land price for land in each zone. The locational surplus makes it possible to deal with the locational competition among land-use activities and the locational preference of each activity at the same time. They applied this model to a suburban area of Tokyo and examined the reliability of the model. Nakahara and Ohota (1983) developed a qualitative land-use model for Sapporo City. This model estimates the land-use type of each 500 meter square grid using land-price estimation functions and land-use discriminant functions. Sasaki and Asakura (1984) applied the game theory to the prediction of land-use pattern in Osaka City. In their model, the potential of each zone for each land-use activity is estimated using the land-price function, and the locational competition among activities is simulated by applying the game theory.

These models aim at coping with the complex mechanism of land-use formation in Japanese cities, and consider various locational factors in order to explain the diverse quality of land. However, the behaviour of participants in demand and supply aspects in a land market is not explicitly considered in these models. The land-use model in this paper aims to simulate the mechanism of land market using the concept of bid price. The model has the following features:

(1) The behaviours of participants in demand and supply aspects in a land market are modelled using the idea of bid price, and a future land-use pattern is predicted by simulating a bidding competition among land-use activities.

(2) The behavioral criteria of the supply and demand aspects are explicitly considered in this model. The land is assumed to be supplied to the activity which shows the highest bid price, and each activity is assumed to demand the land where the highest locational attractiveness is expected.

(3) The bid price of each activity is assumed to be normally distributed around an average bid price owing to the variety of locational preferences and insufficient information about land attractiveness.

\section{THE STRUCTURE OF THE LAND-USE MODEL}

\section{(1) The model structure and submodels}

The land-use model described in this paper is a modified version of the lower Land-use Model of our Hierarchical Urban Model (Amano, Toda and Abe, 1983). It has been revised to simulate the bidding competition among land-use activities in each lot. Fig. 1 shows the structure of the Hierarchical Urban Model. The totality of activities in a metropolitan area are allocated in a hierarchical manner using two subsidiary models; the Activity Location Model and the Land-use Model. The Activity Location Model estimates the activity level of various kinds of employment and population in each large zone. These employment and population estimates are converted into demand for land. This demand is allocated to small zones using the Land-use model described in this paper. The basic structure of the Activity Location Model has been already presented by Amano and Abe (1985) .

In the Land-use Model, the behaviour of the demand and supply aspects in a land market is modelled using the concept of bid price. The future

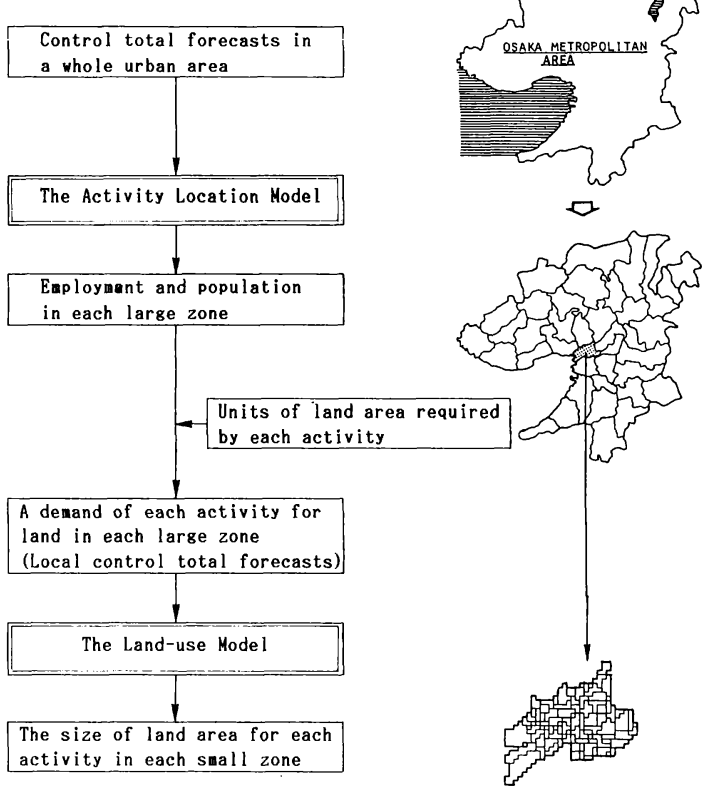

Fig. 1 The Basic Structure of the Hierarchical Urban Model 
land-use pattern is estimated by simulating a bidding competition among activities in each lot. The Land-use Model estimates the land-use patterns for four kinds of land-use activities;manufacturing, commerce, residence and agriculture. The model is composed of four submodels as shown in Fig. 2.

The Bid-price Submodel estimates an average bid price for lots in each small zone using hypothetical relationships between the bid price and the land price. The Land-use Trend Submodel simulates the bidding competition among activities in each lot using the idea of bid price. Its output is the number of lots which can be supplied to each activity. The Land-use Demand Submodel allocates the total demand to each lot in each small zone according to the attractiveness and suitability of land for activities. The supply and demand obtained in the above submodels are adjusted to equilibrium by the Land-use Settlement Submodel, and the final land-use pattern in each small zone is determined.

(2) The bid-price submodel

When each activity demands a land, it appraises the attractiveness of the land and determines a bid price as a measure of willingness to pay. In this submodel, an existing activity which occupies a lot is regarded as a land supplier. When the bid price of the demand side exceeds the offer price of the supply side, negotiation between supply and demand sides occurs, and the negotiated price is the land price for the lot. Therefore, the bid price of each activity can be estimated through the analysis of land price. However, we face the problems of data requirement and computation, when we estimate a bid price of each activity for each lot. A stochastic approach is applied under two assumptions to cope with these problems.

Firstly, the bid price of activity $k$ for lot $l$ in small zone $r, B_{r l}^{k}$ is assumed to be distributed around the average bid price for lots in each small zone $B_{r}^{k}$. That is,

$$
B_{r l}^{k}=B_{r}^{k}+\delta_{r l}^{k}
$$

where,

$\delta_{r l}^{k}$ : a stochastic component of bid price

The stochastic component $\delta_{r l}^{k}$ is assumed to be a normal stochastic variable with variance $\sigma_{k}^{2}$. That is,

$$
\Phi(x)=\frac{1}{\sqrt{2 \pi} \cdot \sigma_{k}} \exp \left(-\frac{x^{2}}{2 \cdot \sigma_{k}^{2}}\right)
$$

Therefore, $B_{r l}^{k}$ has a normal distribution $N\left(B_{r}^{k}, \sigma_{k}^{2}\right)$.

Secondarily, it is assumed that an average bid price $B_{r}^{k}$ is equal to an average land price for lots in each small zone. The average land-price is estimated using the average land-price estimation function. Fig. 3 illustrates the relationship between the bid price and the land-price estimation function for two activities. The land-price estimation function is formulated as a linear equation. Its independent variables include various factors relevant to the land price, such as transport accessibility indices, infrastructure indices. The variance $\sigma_{k}^{2}$ is obtained as the variance of the residual in the calibration of the land-price estimation function.

According to these assumptions, $B_{r l}^{k}$ is estimated by applying the Monte Carlo method, which generates many random numbers following the normal distribution $N\left(B_{r}^{k}, \sigma_{k}^{2}\right)$ as shown in Fig. 3 .

The offer price of an existing activity is generally higher than that of a new activity because of the demolition and relocation costs and an intentional rise in offer price of the existing activity. In this model, 


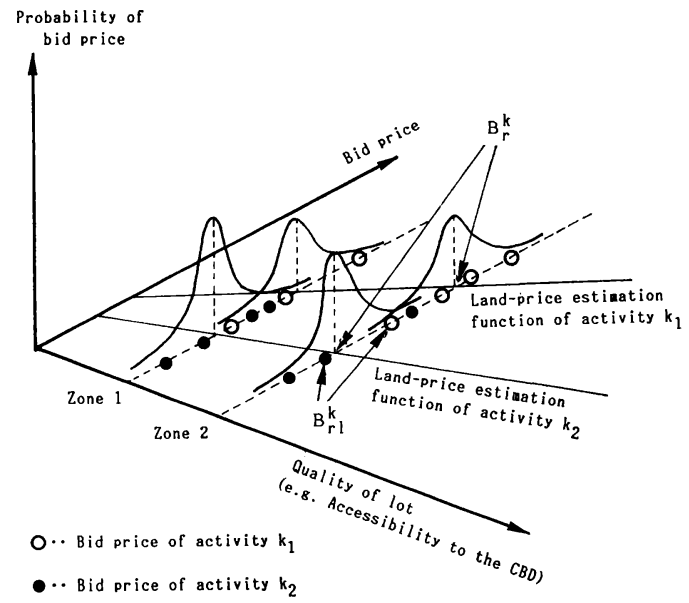

Fig. 3 The Relationship between the Bid Price and the Land Price.

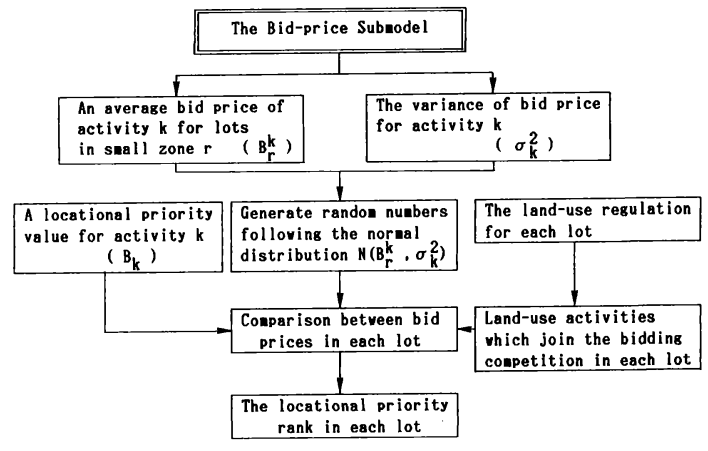

Fig. 4 The Simulation Procedure in the Land-use Trend Submodel.

this dominance of existing activities is considered as a locational priority value $B^{k}$. Therefore, the bid price of activity $k, B_{r l}^{k}$ is defined as follows :

$$
B_{r l}^{k}=B_{r}^{k}+B^{k}+\delta_{r l}^{k}
$$

for existing activities

$$
B_{r l}^{k}=B_{r}^{k}+\delta_{r l}^{k}
$$

for new activities

(3) The land-use trend submodel

The land in each small zone is divided into many small lots. These lots represent the hypothetical units which are treated among land-use activities. The area of a lot is assumed to be $10^{4} \mathrm{~m}^{2}$ in the application.

The Land-use Trend Submodel simulates the bidding competition among activities using the bid price of each activity for a lot. It is assumed that a lot is supplied to the activity which shows the highest bid price. The bid prices for a lot are compared among activities, and the locational priority rank of each activity in each lot is determined. The output from this simulation is the number of lots supplied for each activity.

Fig. 4 shows the simulation procedure in this submodel. Firstly, a bid price of each activity for a lot is estimated using the normal distribution $N\left(B_{r}^{k}, \sigma_{k}^{2}\right)$. Secondarily, land-use activities which join the bidding competition for a lot are determined by reference to the land-use regulation for the lot. Then the bid prices for the lot are compared among activities, and the locational priority rank of each activity is determined. This rank shows the priority of location in each lot among activities in the prediction time.

(4) The land-use demand submodel

In this submodel, the demand of each activity for lots is estimated in each large zone. Each activity compares the locational attractiveness among lots, and demands the lot where the highest attractiveness is obtainable.

A bid price of an activity for each lot is used for the index of locational attractiveness. It is estimated by applying the Monte Carlo Method in Section 2. (2). The locational attractiveness rank is determined by comparing bid prices of an activity among lots in a large zone. The higher rank of a lot shows the higher locational attractiveness of an activity. This rank is combined with the locational priority rank, and an allocation order is determined for each activity and each lot. The higher allocation order represents the higher locational attractiveness and the stronger competitiveness for the lot. These relationships are summarized in a locational rank table, which is exemplified in Table 1. Commerce shows the highest allocation order for Lot No. 952 in Table 1, and is first allocated to the lot in the Land-use Settlement Submodel. 
(5) The land-use settlement submodel

The control total forecast of each activity, which is obtained for each large zone in the Activity Location Model, is allocated to each lot in the Land-use Settlement Submodel. However, the total land-use supply, which is estimated in the above three submodels, is generally not consistent with the control total forecast for each large zone.

The following adjustment procedures are applied to determine the final land-use pattern in each large zone.

(1) If the control total forecast of an activity exceeds the land-use supply, the unused lots are assumed to be developed for the activity, and they are allocated to the excess control total in proportion to the bid price of each activity.

(2) If the land-use supply exceeds the control total forecast, the excess land-use supply is left as unused lots.

\section{CALIBRATION OF THE MODEL FOR THE OSAKA PREFECTURAL AREA}

\section{(1) The study area and the data base}

The model has been applied to the Osaka Prefectural Area, which is shown in Fig. 5. This area had a population of about 8.2 million in 1978 and its area is $1861 \mathrm{~km}^{2}$. This central part of the Osaka Metropolitan Area contains 13 large zones of the Activity Location Model and was further disaggregated into 841 small zones for the Land-use Model. Each small zone nearly corresponds to a residential zone and is composed of several 500 meter square grids. The control total forecast of each land-use activity in each large zone is given exogenously by the Activity Location Model, and the land-use pattern in each small zone is estimated by the Land-use Model.

Various kinds of data in each small zone were processed from 500 meter square grid data which were available from the Osaka Prefectural Government. The data for land prices in 1975, which were published

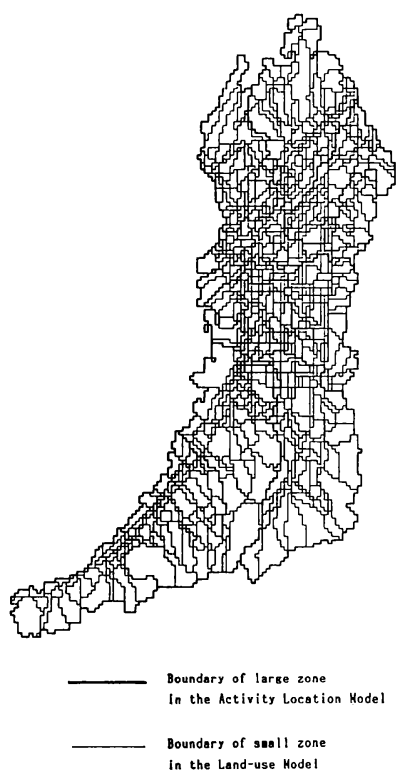

Fig. 5 The Study Area and the Zoning System in the Land-use Model.

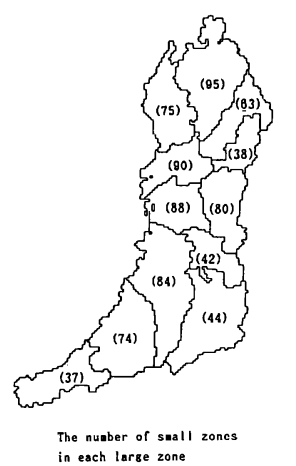

Table 2 The Land-price Estimation Function for Each Land-use Activity.

\begin{tabular}{|c|c|c|c|c|}
\hline $\begin{array}{l}\text { Land-use } \\
\text { activity }\end{array}$ & $\begin{array}{l}\text { Explanatory } \\
\text { variable }\end{array}$ & Unit & $\begin{array}{l}\text { Parameter } \\
\text { ( } t \text { value) }\end{array}$ & \\
\hline Manufacturing & $\begin{array}{l}\text { (1) Accessibility to manufacturing } \\
\text { activity } \\
\text { (2) Distance to the nearest } \\
\text { highway IC } \\
\text { (3) Employment of secondary } \\
\text { industries } \\
\text { (4) Average number of floors } \\
\text { in each small zone } \\
\text { (5) Constant term }\end{array}$ & $\begin{array}{c}- \\
\text { km } \\
\text { person } \\
- \\
-\end{array}$ & $\begin{array}{l}0.209 \times 10^{-2} \\
(6.52) \\
-0.0103 \\
(0.68) \\
0.204 \times 10^{-2} \\
(0.39) \\
70.68 \\
(2.91) \\
271.71\end{array}$ & $\begin{array}{c}\overline{\mathrm{R}}^{2}=0.616 \\
\text { Standard } \\
\text { error } \\
=163.7\end{array}$ \\
\hline Commerce & $\begin{array}{l}\text { (1) Accessibility to service } \\
\text { activity } \\
\text { (2) Distance to the nearest } \\
\text { railway station } \\
\text { (3) Employment of tertiary } \\
\text { industries } \\
\text { (4) Average number of floors } \\
\text { in each small zone } \\
\text { (5) Constant term }\end{array}$ & $\begin{array}{c}\text { km } \\
\text { person } \\
\text { - }\end{array}$ & $\begin{array}{r}0.0293 \\
(2.00) \\
-203.7 \\
(1.81) \\
0.0263 \\
(2.65) \\
460.6 \\
(5.23) \\
535.58\end{array}$ & $\begin{array}{c}\bar{R}^{2}=0.377 \\
\text { Standard } \\
\text { error } \\
=1529.5\end{array}$ \\
\hline Residence & $\begin{array}{l}\text { (1) Accessibility to work } \\
\text { place } \\
\text { (2) Distance to the nearest } \\
\text { railway station } \\
\text { (3) Percent of drainage } \\
\text { provision } \\
\text { (4) Average number of floors } \\
\text { in each small zone } \\
\text { (5) Constant term }\end{array}$ & $\begin{array}{c}\cdot \\
\mathrm{km} \\
\% \\
-\end{array}$ & $\begin{array}{r}0.0417 \\
(12.76) \\
-43.03 \\
(6.11) \\
1.931 \\
(6.25) \\
76.46 \\
(4.55) \\
237.16\end{array}$ & $\begin{array}{l}\overline{\mathrm{R}}^{2}=0.645 \\
\text { Standard } \\
\text { error } \\
=178.0\end{array}$ \\
\hline
\end{tabular}


by the National Land Agency, were also used in this model.

(2) Calibration of the land-price estimation function

The land-price estimation functions were calibrated using land-price data for 1975 . These data were collected at 1811 points in the Osaka Prefectural Area and were classified into manufacturing, commercial and residential use areas. Each function was calibrated by applying a multiple regression analysis. Table 2 shows the results of calibration. The accessibility indices in Table 2 are defined by the following equation.

$$
A C S_{i}=\sum_{j} A_{j} \cdot \exp \left(-\alpha \cdot t_{i j}^{m}\right)
$$

where,

$A C S_{i}:$ the level of accessibility in zone $i$

$A_{j}:$ the activity level in zone $j$

$t_{i j}^{m}:$ the travel time between zones $i$ and $j$ by the transport mode $m$

$\alpha:$ a distance exponent

The definition of each accessibility index is shown in Table 3. The distance exponent of each accessibility index was estimated using the transportation survey data in the Osaka Prefectural Area. The estimated values for $\alpha$ are 0.0534 for manufacturing, 0.0574 for commerce and 0.0557 for residence.

The standard error of each function corresponds to $\sigma_{k}$ in Equation (2). As agriculture is not assumed to bid a price for a lot occupied by other land-use activities, its land-price estimation function is not formulated. The average number of floors in each zone is introduced to consider the effect of high rise buildings on land price in each zone. This variable is excluded from the land-price estimation function in calculating the average land-price in each zone. Estimation results for manufacturing and residence are fairly high, whereas the coefficient for commerce is low. This refelects the diversity of land prices in commercial use areas. The $t$ values show that the accessibility indices are important factors for the formation of land price in manufacturing and residential use areas. The average number of floors is the most significant factor in commerce, which resulted from the multistoried use in commercial areas.

(3) Estimation of the locational priority value and the locational restriction for each activity

The locational priority value, which represents the locational priority of existing activities against new activities, should be estimated through the analyses of relocation costs of existing activities. However, in this study, this value was set by minimizing the RMS error in land area of each activity for the prediction time. The estimated values are shown in Table 4.

The location of each land-use activity is strictly regulated by the City Planning Act. In the Land-use Model, the location of each land-use activity is restricted according to the present land-use regulation in

Table 3 The Definition of Each Accessibility Index.

\begin{tabular}{llcc}
\hline Activity & Accessibility Index & $\begin{array}{l}\text { Transport } \\
\text { node }(\mathrm{m})\end{array}$ & $\begin{array}{c}\text { Activity level } \\
(\mathrm{A} i)\end{array}$ \\
\hline Manufacturing & $\begin{array}{l}\text { Accessibility to } \\
\text { manufacturing activity }\end{array}$ & Car & $\begin{array}{l}\text { Employment in } \\
\text { Manufacturing }\end{array}$ \\
Comerce & $\begin{array}{l}\text { Accessibility to } \\
\text { comercial activity }\end{array}$ & Car & $\begin{array}{l}\text { Enployent in } \\
\text { connerce }\end{array}$ \\
Residence & $\begin{array}{l}\text { Accessibility to } \\
\text { vorkplace }\end{array}$ & Railvay & Population \\
\hline
\end{tabular}

Table 4 The Locational Priority Value $B^{k}$.

\begin{tabular}{lc}
\hline $\begin{array}{c}\text { Land-use } \\
\text { activity }\end{array}$ & $\begin{array}{l}\text { Locational priority } \\
\text { value }\end{array}$ \\
\hline Hanufacturing & 500 \\
Comerce & 600 \\
Residence & 600 \\
Agriculture & 400 \\
\hline
\end{tabular}

Table 5 Locational Restrictions According to the Land-use Regulation System.

\begin{tabular}{|c|c|c|c|c|c|}
\hline & \multirow[b]{2}{*}{ Land-use area } & \multicolumn{4}{|c|}{ Land-use Activity } \\
\hline & & $\begin{array}{l}\text { Manufac- } \\
\text { turing }\end{array}$ & Connerce & Residence & $\begin{array}{l}\text { Agricul- } \\
\text { ture }\end{array}$ \\
\hline (1) & $\begin{array}{l}\text { Class } 1 \\
\text { residential area }\end{array}$ & $\times$ & $x$ & $\mathrm{O}$ & $x$ \\
\hline (2) & $\begin{array}{l}\text { Class } 2 \\
\text { residential area }\end{array}$ & $x$ & $\mathrm{O}$ & 0 & $x$ \\
\hline (3) & Residential area & 0 & 0 & 0 & $x$ \\
\hline (4) & $\begin{array}{l}\text { Neighbourhood } \\
\text { connercial area }\end{array}$ & 0 & 0 & 0 & $x$ \\
\hline (5) & Connercial area & 0 & 0 & 0 & $x$ \\
\hline (B) & $\begin{array}{l}\text { Seni-industrial } \\
\text { area }\end{array}$ & 0 & 0 & 0 & $x$ \\
\hline (7) & Industrial area & 0 & 0 & 0 & $x$ \\
\hline (8) & $\begin{array}{l}\text { Exclusive } \\
\text { industrial area }\end{array}$ & $x$ & 0 & 0 & 0 \\
\hline (9) & $\begin{array}{l}\text { Urbanization } \\
\text { control area }\end{array}$ & 0 & 0 & 0 & $x$ \\
\hline
\end{tabular}


each lot. Table 5 shows the relationships between the land-use regulation system of the City Planning Act and the locational restrictions in the Land-use Model.

(4) The validation of the model

The model was applied to the Osaka Prefectural Area, and the land-use pattern in each small zone was forecasted for 1978 using data for the base year, 1973. The reliability of the model was examined by comparing predicted and real values for 1978 .

Table 6 shows the correlation coefficients between the estimated and the real values of land area for 841 small zones in the Osaka Prefectural Area. The correlation coefficients for the land area in 1978 are high. However, those for the changes in land area of manufacturing, commerce and agriculture are low. Fig. 6 shows the scattergram of each activity for the changes in land area. Although the correlation coefficients are low, the tendencies of the changes in land area are predicted fairly well.

There are a few zones, which show large differences between real and predicted values, in the scattergrams of manufacturing and commerce. The over-and under-estimated zones in the scattergram of manufacturing contains industrial sites in coastal and inland areas. The mis-prediction is possibly caused by the planned developments and relocations of industrial sites.

A few zones show large increases in agricultural land area. As agricultural land is assumed not to increase in the model, the under-estimation has occurred. These irregular changes in manufacturing and agriculture should have been treated exogenously in the model.

The changes in land area of commerce are generally small due to the multistory commercial area. Although it is included as one of the independent variables in the land price estimation function, additional refinements will be necessary to improve the model.

\section{A CASE STUDY OF THE MODEL}

The Land-use Model has been applied to various kinds of impact studies as a subsidiary model of the Hierarchical Urban Model. In this paper, we describe a case study concerning the regional transport network planning in the Osaka Metropoli$\tan$ Area.

Fig. 7 shows the new railway routes which has been proposed in the Kansai International Airport Project. The model was applied to investigate major impacts on the land-use pattern under the construction of this railway network. The predictions were carried out under the following two cases.

Case 1 : New railway routes are not constructed.

Case 2 : New railway routes are constructed.

The model was run four times in a recursive

Table 6 The Results of Validation for the Land-use Model.

\begin{tabular}{lcc}
\hline & \multicolumn{2}{c}{ Correlation coefficients } \\
\cline { 2 - 3 } Land-use activity & Land-use in 1978 & $\begin{array}{c}\text { Land-use change } \\
\text { fron 1973 to 1978 }\end{array}$ \\
\hline Hanufacturing & $\mathbf{0 . 9 7 0}$ & 0.291 \\
Connerce & 0.881 & 0.386 \\
Residence & $\mathbf{0 . 9 7 2}$ & 0.743 \\
Agriculture & $\mathbf{0 . 9 7 5}$ & 0.315 \\
\hline
\end{tabular}

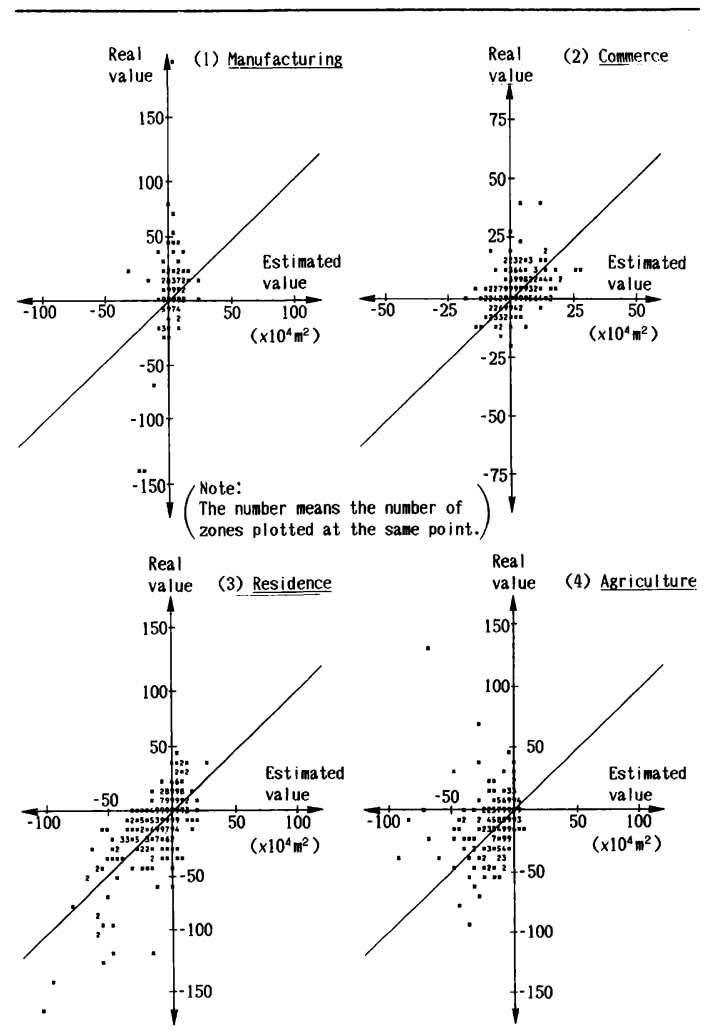

Fig. 6 The Estimated and Real Values for the Changes in Land Area. 


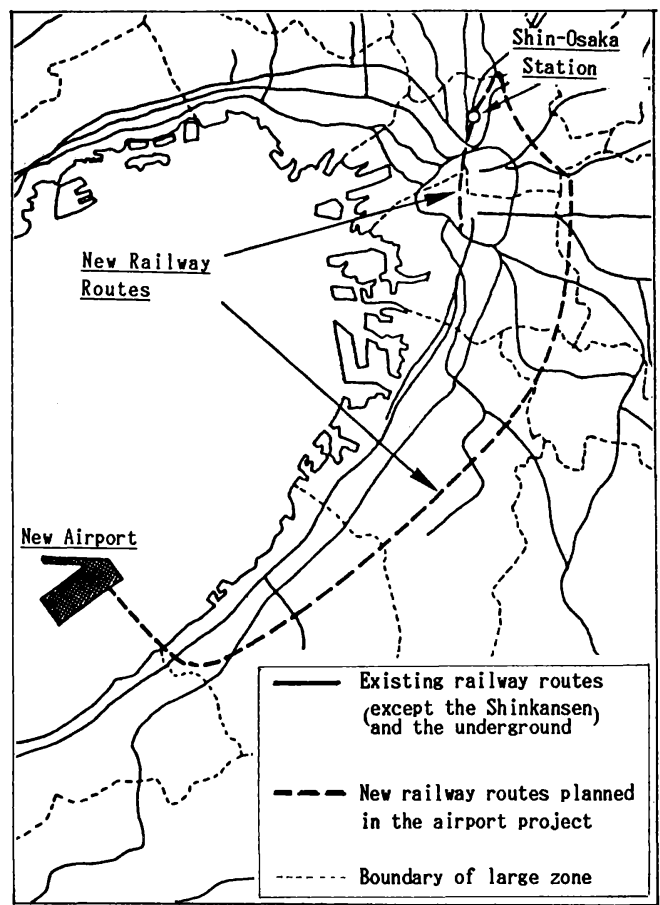

Fig. 7 New Railway Routes Planned in the Airport Project.
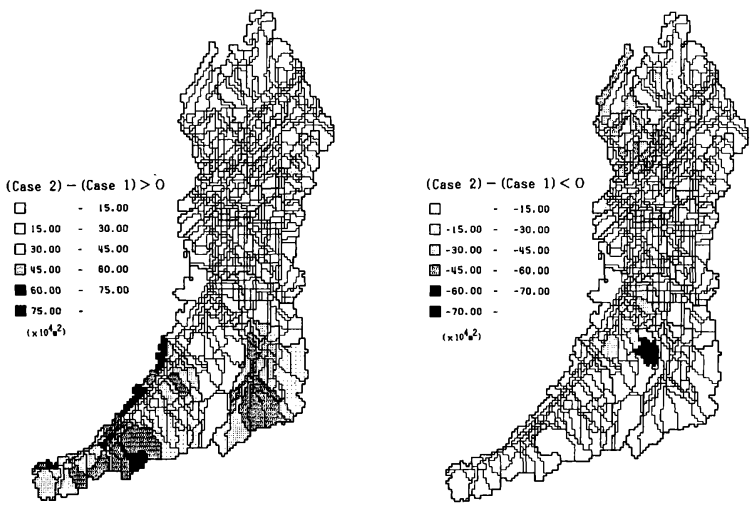

Fig. 8 The Results of Prediction for the Residential Land Areas.

manner during the period from 1973 to 1993 , and the land-use pattern in 1993 was predicted. The control total forcasts of each land-use activity were estimated by the Activity Location Model and were given exogenously to the Land-use Model.

Fig. 8 shows the results of prediction for the residential land-use. In this figure, each result is shown as a difference between the above two cases.

The residential land area is predicted to increase

greatly in the south of the Osaka Prefectural Area. These zones are located close to the railways which are newly constructed in the project. These results indicate large improvements of locational attractiveness in these zones.

\section{CONCLUSIONS}

In this paper, a land-use simulation model based on the bidding competition among land-use activities has been proposed. This model enables to consider the following aspects of land-use formation.

(1) Locational competition in each lot is explicitly considered by simulating the bidding competition among land-use activities. Existing activities are also assumed to bid prices for their own lots. This idea makes it possible to estimate the change in land-use from the existing use to other uses.

(2) The bid price of each activity is assumed to be normally distributed around the average bid price for lots in each zone. This stochastic approach makes it possible to cope with the uncertainty of locational preference of each activity and the insufficient information about land attractiveness.

(3) The land-price estimation function, which estimates the average bid price of each activity for lots in each zone, includes various kinds of factors as explanatory variables. The effects of various policies on the land-use pattern are examined by changing the level of each explanatory variable.

(4) The land-use regulation system based on the City Planning Act and the intentional behaviors of the existing activity in each lot are explicitly considered in the model. These features have made the model more operational for actual land-use planning.

The application of the model to the Osaka Prefectural Area revealed that the model's estimation reliability was generally satisfactory. Moreover, the effective use of the model for the impact analysis on the transport network planning was presented. However, in order to increase the reliability of the model, especially for manufacturing and commercial land uses, additional refinements will be required. 


\section{REFERENCES}

1) Alonso, W. : Location and Land Use, Harvard University Press, Cambridge, Mass, 1964.

2) Amano, K. , Toda, T. and Abe, H. : A Hierarchical Urban Model and Its Application to the Osaka Metropolitan Area, A paper presented to the 23 rd European Congress of Regional Science Association held in Poitier, France, 1983.

3) Amano, K. and Abe, H. : An Activity Location Model for a Metropolitan Area, Infrastructure Planning Review, Vol. 2, 165-172, 1985 (In Japanese).

4) Anas, A. : Residential Location Markets and Urban Transportation, Academic Press, 1982.

5) Aoyama, Y. and Morisugi, H. : A Study on the Preference Function Characteristic of Location of Urban Land User, Annual Papers of Regional Science Association of Japan, Vol. 1, 41-61, 1970 (In Japanese).

6) Beckmann, M. J. : On the Distribution of Urban Rent and Residential Density, Journal of Economic Theory, 1 , 1969.

7) Herbert, J. D. and Stevens, B. H. : A Model for the Distribution of Residential Activity in Urban Area, Journal of Regional Science, 2, 21-36, 1960 .

8) Ingram, G. K., Kain, J. F. and Ginn, J. R. : The Detroit Prototype of the NBER Urban Simulation Model, National Bureau of Economic Research, New York, 1972.

9) Mills, E. S. : An Aggregate Model of Resource Allocation in a Metropolitan Area, American Economic Review, Vol. 57, No. 2, 1967.

10) Muth, R. F. : Cities and Housing, Chicago Press, 1969.

11) Nakahara, H. and Ohota, M. : A Study on the Change in Urban Land Use through Analysis on Land Value, Papers of the Annual Conference of the City Planning Institute of Japan, No. 18, 241-246, 1983 (In Japanese).

12) Nakamura, H., Hayashi, Y. and Miyamoto, K. : A Land Use Model for Suburban Area, Proceedings of Japan Society of Civil Engineers, No. 309, 103-112, 1981 (In Japanese).

13) Sasaki, T. and Asakura, Y. : A Land-use Model Considering the Competition of Location of Economic Activities in Urban Area, Proceedings of Japan Society of Civil Engineers, No. 347/IV-1, 85-93, 1984 (In Japanese). 